Article

\title{
Learning from Alliance Membership: An Empirical Study of Learning from the Failure of Their Alliance Members, Liability and Environmentally Sustainable Airline
}

\author{
Euisin Kim ${ }^{1, *}$ and Mooweon Rhee ${ }^{2}$ \\ 1 School of Business, Kyung Hee Cyber University, Seoul 02447, Korea \\ 2 School of Business, Yonsei University, Seoul 03722, Korea; mooweon@yonsei.ac.kr \\ * Correspondence: eskim8@khcu.ac.kr
}

Citation: Kim, E.; Rhee, M. Learning from Alliance Membership: An Empirical Study of Learning from the Failure of Their Alliance Members, Liability and Environmentally Sustainable Airline. Sustainability 2021, 13, 11794. https://doi.org/ $10.3390 /$ su132111794

Academic Editor: Lynnette Dray

Received: 14 September 2021

Accepted: 19 October 2021

Published: 26 October 2021

Publisher's Note: MDPI stays neutral with regard to jurisdictional claims in published maps and institutional affiliations.

Copyright: (c) 2021 by the authors. Licensee MDPI, Basel, Switzerland. This article is an open access article distributed under the terms and conditions of the Creative Commons Attribution (CC BY) license (https:// creativecommons.org/licenses/by/ $4.0 /)$.

\begin{abstract}
Through this research, we examined whether airlines vicariously learn more from accidents of alliance members. We set organizational learning as our dependent variable and defined it as a reduction in the subsequent accident rate. Our research also examined the moderating effect of liability (U.S. air carriers) by hypothesizing that U.S. air carriers are more likely to learn from alliance memberships. In sum, the results of our analyses showed that an airline is more likely to learn from alliance members' failure experiences. Furthermore, findings of the moderating effect of liability (U.S. air carriers) revealed that U.S. air carriers are more likely to learn from alliance memberships. In addition, findings on the moderating effect of environmentally sustainable airlines revealed that an environmentally sustainable airline is more likely to learn from alliance memberships. This research was examined using the accidents database from the U.S. National Transportation Safety Board (NTSB) of world commercial airlines from 2008 to 2018. We contributed to the previous line of research that explored factors influencing organizational learning and the benefits of forming alliances. The findings of this research could apply to other fields with alliances and accidents.
\end{abstract}

Keywords: learning from alliance; organizational learning; learning from failure; learning from liabilities; environmentally sustainable airline; environmental sustainability

\section{Introduction}

Since 1989, it has become prevalent among international airlines that alliance memberships formed among airlines provide numerous benefits to their members. Airline alliances (The currently existing airline alliances are Star Alliance, One World Alliance, Sky Team Alliance, and Value Alliance [1-6]. Among the alliance groups, the top three major alliances with the most members were Star Alliance, One World Alliance, and Sky Team Alliance $[1,3,6]$. Appendix A (Table A1) demonstrates the membership of alliances. Since the establishment of alliance groups, the membership of alliances has been fluctuating, as some carriers made the decision to recently join the alliance group and some members made the decision to drop from the alliance group. According to Appendix A (Table A1), there are 26 members in Star Alliance [1], 13 members in One World Alliance [3], and 19 members in Sky Team Alliance [6]) may be defined as cooperative agreements between more than two airlines that allow mutual operation among airlines to increase general performance and competitive advantages [7]. The main benefits of alliances consist of accessing new markets through code sharing, block spacing [8], shareholding [9], franchising [8], performing joint aircraft repair and maintenance, sharing ground handling [7], and achieving cost savings and economies of scale through joint marketing and sales campaigns [8]. As a consequence of these airline alliances, alliance member carriers are able to charge customers lower prices for tickets compared to non-allied carriers [10,11] and achieve increases in profitability [12]. Airline alliances are very important as they always seek strategies to increase growth rates $[13,14]$. 
Extending beyond the benefits of the alliances mentioned above, we attempted to link airline alliances with the reduction in airlines' subsequent accident rates, which affect environmental sustainability. We emphasized whether airlines learn from their alliance members' failures, wherein learning is presented as a reduction in an airlines' subsequent accident rate (One may suspect that as an alliance group requires high standards of safety when they invite a new member to join the alliance group, fewer accidents are likely to occur. However, these pre-high-safety standards are irrelevant to our study as the time frame of our analysis starts at the point after members join the alliance group; therefore, our study focused on whether vicarious learning occurs from alliance members' accidents). Reducing airline accidents is crucial to environmental sustainability. In general, aviation impacts environmental sustainability in perspectives of pollutions such as building airports and infrastructures, noise from aircraft, air pollution caused by aviation emission, and water pollution caused by waste oil [15]. The amount of aviation emissions, such as greenhouse gas emissions from international airlines, is emphasized as an indicator of environmental sustainability in air transportation [16,17]. Relating environmental sustainability and airline accidents, airline accidents have caused serious issues in the environment, such as water pollution caused by oil leaks from broken aircraft or uranium pollution created by the 1992 Boeing 747-258F plane crash in Amsterdam [15,18]. As mentioned above, reducing airline accidents assists environmental sustainability.

Previous learning from failure studies in various fields has been divided into two main research streams. The first is learning from one's own errors [19-21], and the second is vicarious learning, which is learning from others' errors [22,23]. Extending further on vicarious learning, we focused on in-group vicarious learning from failure, which is learning from accidents of alliance members. Previous research on vicarious learning has claimed that generalists seem to learn from the failures of others as they have better access to external information and are more likely to respond to external pressures, as regulatory agencies put more pressure on generalists [19]. Similarly, alliance memberships are formed on a team basis and are greater in size than individual airlines are; therefore, alliance memberships tend to have more access to external information. Additionally, they are more responsive to external pressures from regulatory agencies (FAAs) and have access to information on alliance members' accident experiences to learn from the failures of others. In addition, alliance members tend to share information on accidents through annual meetings and perform alliance-based internal safety checks in addition to regulatory agencies' (FAA) safety checks [24]. Sharing information regarding accident information and safety issues is considered important because if airlines fail to meet safety standards, alliance membership could be jeopardized. For example, Korean Airlines suffered from poor safety records due to terrorism events, which caused Air France to temporally cease its code-sharing agreement [24]. The occurrence of accidents due to poor safety management could lead to dreadful consequences, and lowering the accident rate by learning from shared team information, such as alliance members' accidents, is mandatory. In sum, alliance members tend to share accident information, pay attention to alliance members' accidents, and learn from them. As the first research question in this research, we were interested in whether airlines learn more from their alliance members' failures. As our second research question, we were interested in whether liability (U.S. air carriers) moderates the relationship between alliance membership and an airline's subsequent error rate. As our third research question, we were interested in whether an environmentally sustainable airline moderates the relationship between alliance members and an airline's subsequent error rate.

As most of the previous learning from failure literature has paid attention to learning from one's own error experience [19-21] and others' error experience [22,23], less research has paid attention to vicarious learning from the failure of alliance members. Some studies on vicarious learning among chain members have been performed [25], which are similar to vicarious learning among alliance members. However, their main focus was on other industries, which leaves doubt about their generalization to the airline industry, as their 
focus was on learning from failure. While previous aviation studies have focused on the various benefits of alliance among airlines [8-12], our research extended the benefits of alliance membership to the reduction in airlines' subsequent accident rates after learning from alliance members' accidents, which also leads to environmental sustainability.

To respond to our research questions, we tested the model presented in Figure 1. We examined our model on a panel using an accident database of world commercial airlines from 2008 to 2018. We were able to gather data from the U.S. National Transportation Safety Board (NTSB).

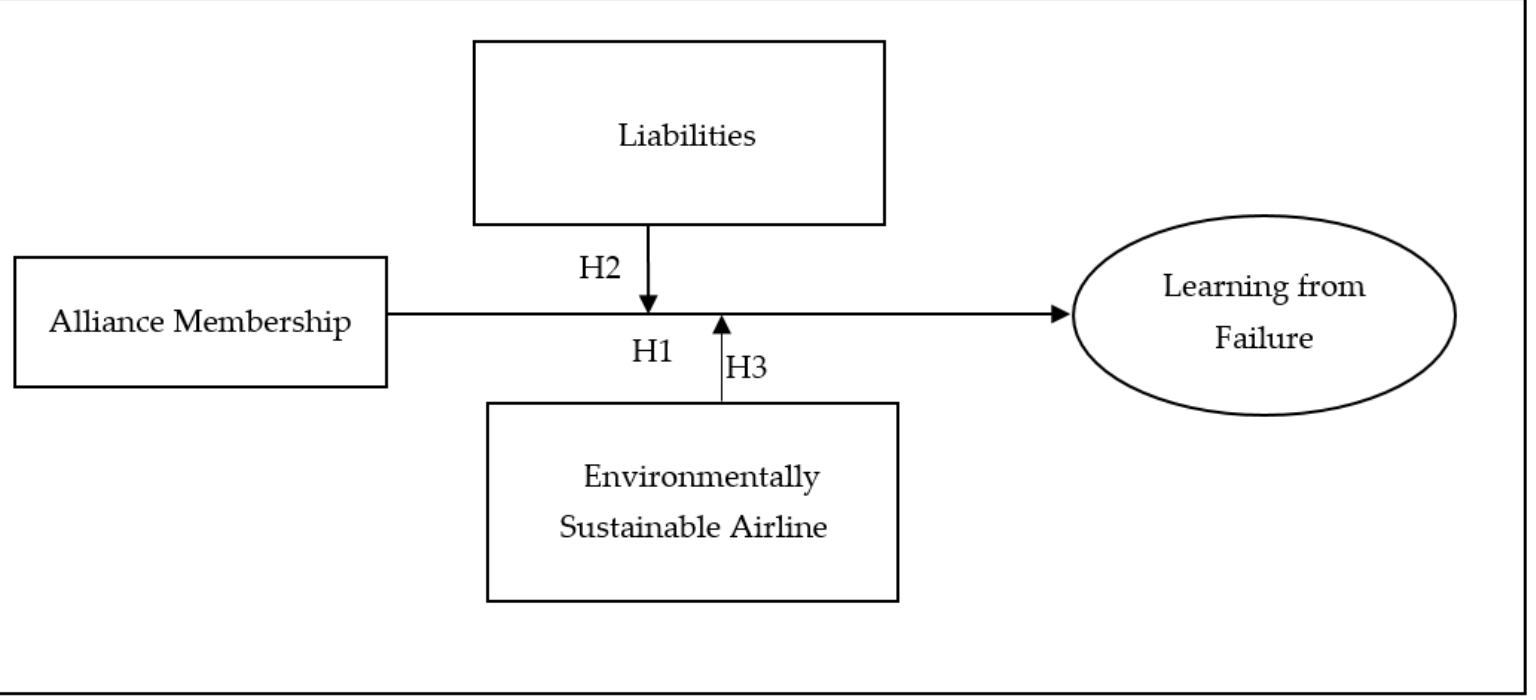

Figure 1. Model of vicarious learning from failure among alliance members.

\section{Theory and Hypotheses}

\subsection{Vicarious Learning from Alliance Members' Accidents}

As most scholars of organizational learning have explored learning from one's own experience of failure [19-21,26], scholars have started to pay attention to learning from others' failures [22,23,27-29]. According to Weick et al. [30], others' failures could be salient and educational in helping to generate knowledge that leads to reducing the number of future accidents [22,27,31-33]. Learning from others' failures is critical to the survival of firms as not all organizations are provided with abundant chances to experience failure, such as accidents and recalls, which would bring dreadful consequences for management [30]. These insufficient chances to experience failure lead airlines to learn from others' failures to solve the problems they face. Miner, Kim, Holzinger, and Haunschild [34] mentioned that observing other organizations' failures works as an awakening signal for those looking for new strategies.

While it is difficult to learn from other organizations' failures as they are not always open to the public, widely revealed information and knowledge, such as accidents or recalls disseminated and circulated within organizational networks, could facilitate organizations to learn from failure. The literature on learning among chain members extends general vicarious learning to specific types of in-group vicarious learning, such as affiliations or alliances, in which the transition of learning occurs as the chain's learning curve is raised by keeping up with standardized routines among members [25,35-37]. Baum, Li, and Usher [38] described learning through alliance networks as "learning communities" [22]. Through affiliations, organizations could lower the uncertainty caused by a lack of information about inexperienced new environments. In addition, hotel networks such as hotel chains tend to learn more rapidly than individual hotels do as they have access to the hotel chain's experiences [25]. Similar to chains, airline alliances are formed to increase performance by code-sharing their flights, leading to the extension of their destination [24]. 
By forming alliances, safety checks among alliance members are executed at the alliance headquarters, a level beyond regulatory safety checks. In addition, the Chief Executive Board meetings work as an integration component wherein alliance members are gathered to make decisions, communicate, or consult committees [39]. For example, Star Alliance holds regular Star Alliance Chief Executive Board meetings twice a year [39-41]. In the meetings, they discuss problems commonly faced by alliance members, such as customer services or safety accident issues. As part of the discussions, Star Alliance, as well as other alliance groups, has set emergency response procedures, which means assistance is provided by alliance members when an accident occurs [42]. For instance, United Air helped in the aftermath of the crash of Asiana Air, as they are both members of Star Alliance. Due to emergency response procedures, alliance members share information regarding the accidents for assistance [42]. In sum, through regular meetings among alliance members, information on accidents is shared among members; therefore, in-group vicarious learning among alliance members occurs.

\section{Hypothesis 1. An airline is more likely to learn from alliance members' failure experiences.}

\subsection{The Moderating Effect of Liabilities (U.S. Air Carriers)}

Through this research, we tested a moderating factor that strengthens or weakens the effect of alliance membership on learning. Findings from studies on learning from failure have revealed that firms learn more from liabilities such as recalls [43]. Specifically, when airline accidents occur, airlines are liable for compensating passengers. When U.S. air carriers are involved in an accident, jurisdictional courts of lawsuits are assigned in the U.S. Based on applying Article 28 of the Warsaw Convention, punitive damage suits are possible. According to Article 28 of the Warsaw Convention (From Article 28 of the Warsaw Convention (translation by the U.S. Department of State): “(1) An action for damages must be brought, at the option of the plaintiff, in the territory of one of the High Contracting Parties, either before the Court of the domicile of the carrier or of his principal place of business, through which the contract has been made, or before the Court at the place of destination" [44]), jurisdictional courts are decided based on four categories: (1) domicile of the carrier, (2) domicile of the principal place of business, (3) domicile of the place of business in which the contract has been made, and (4) the place of destination [44]. Among these four categories, categories related to the availability of information from accidents are the domicile of the carrier. Whether or not to assign a jurisdictional court within the U.S. is an important factor in learning as the compensation made to passengers differs as much as 10-20 times depending on whether lawsuits are assigned to a U.S. or non-U.S. jurisdictional court. For example, in the case of the 2001 accident of American Airlines Flight 587, which killed 265 passengers, USD 2,400,000 in compensation was made for the death of a male passenger whose case was assigned to a U.S. jurisdictional court, as the domicile of the carrier was in the U.S. [45]. In the case of the 1997 accident of Korean Airlines Flight 801, which killed 229 people, USD 250,000 in compensation was made for the death of a passenger whose case was assigned to a Korean jurisdictional court because the domicile of the carrier was in South Korea. As presented above, U.S. air carriers face punitive damage lawsuits, which compensate an astronomical amount of money to passengers-as much as 10-20 times more than Asian countries. They often experience financial difficulties and, in the worst case, file for bankruptcy. In the case of Colgan Air, which operated Continental Connection Flight 3407, an accident occurred, and the parent company of Colgan Air, Pinnacle Air, went bankrupt due to it [46]. To avoid devastating results, airlines make efforts to reduce accidents, especially those airlines that face significant liabilities due to accidents (which, in our case, are U.S. air carriers), who tend to make extra effort to collect information on accidents internally and externally to reduce accidents. As part of making an effort to reduce accidents, U.S. air carriers learn not only from their own errors but also from alliance member accidents. Alliance members are in a better position to collect information on accidents. Through alliance membership, members share overall 
information regarding the accidents of alliance members during regular alliance-teamorganized meetings such as Chief Executive Board meetings held by Star Alliance [39-41], which are related to reducing future failures. In sum, we hypothesize that U.S. Air carriers moderate the relationship between alliance membership and accident rate.

Hypothesis 2. The U.S. air carriers are more likely to learn from alliance memberships.

\subsection{The Moderating Effect of Environmentally Sustainable Airlines}

We examined a moderating factor that strengthens or weakens the effect of alliance membership on learning. Airlines provide various efforts to achieve environmental sustainability [47-50]. As a way to achieve environmental sustainability, an environmentally sustainable airline performs aircraft modernization by replacing old aircraft with new aircraft $[47,50,51]$. Additionally, jet fuel efficiencies are improved through adopting highly fuel-efficient aircraft such as B777-300er, B787-9, and A220-300 [47-52]. Adopting highly fuel-efficient aircraft increased fuel efficiency by $20 \%$, decreased CO2 emissions by $20 \%$, and reduced aircraft noise by $60 \%$ [47]. In addition, sustainable airlines try to reduce plastic waste by replacing plastic straws and coffee stirrers with environmentally friendly materials [47,50]. Among various efforts, highly fuel-efficient aircraft are considered the most important to reaching environmental sustainability [47,52]. According to research by Dzhengiz and Niesten [53], sustainable companies tend to have a high absorptive capacity regarding obtaining external information [54,55]. Applying to our context of airlines, environmentally sustainable airlines are alert and sensitive to external information and are more likely to absorb external information, such as information on alliance members' accidents [53-55]. As alliance members share information regarding accidents within their network through regular alliance-team-organized meetings as mentioned previously [39-41], sustainable air carriers are more likely to learn from alliance memberships.

Hypothesis 3. Sustainable air carriers are more likely to learn from alliance memberships.

\section{Data and Methods}

\subsection{Data}

We collected data on airline accidents for world (domestic and international) commercial airlines between 2008 and 2018 from the U.S. National Transportation Safety Board (NTSB) database. Based on this database, we were able to locate 68 world commercial airlines in operation between 2008 and 2018. As our interest was in how airlines learn from failure, we chose commercial airlines as our unit of analysis.

\subsection{Measures}

\subsubsection{Dependent Variable}

Our dependent variable was set as the annual airline accident rate. We calculated the variable as the number of accidents per 100,000 departures, as similar studies have applied the same rate for computing the accident rate $[19,26,56]$. Throughout the paper, we use the word accidents to only mean accidents but exclude incidents. According to NTSB, an accident is defined as any event that involves human injury, death, or causes fatal damages to facilities and physical assets [19]. An incident is defined as an event that involves a hazard or possible hazard to safety $[19,57]$. We excluded incidents as accidents are more accurately reported [58] as compared to incidents, which are known to be irregularly reported; therefore, possible bias may exist. Using the NTSB database, we were able to obtain the data for the number of accidents $[19,26]$. The data for departures were collected from the U.S. Department of Transportation, Bureau of Transportation Statistics [19,26]. This variable was computed yearly for each airline. 


\subsubsection{Independent Variables}

To calculate our independent variable, vicarious learning from alliance membership, we started by counting the annual number of accidents for each airline as the first step [26]. By following measures from studies on vicarious learning from others' failures [27-29], we used the accidents experienced by other members of the alliance, which is the count of the number of alliance team members' accidents. Furthermore, we accumulated counts of the number of alliance team members' accidents from the previous five years. For example, Delta Air Line's accident on 10 June 2012 was calculated as part of the accumulation of Sky Team alliance members' accidents over the previous five years. To apply the recency effect, we reduced the variable by weighting it. As an example, the data for 2008 were assigned a weight that was $1 / 5$ of the weight assigned to $2012[19,26]$.

\subsubsection{Moderating Variable Liability}

To measure liability, we used the matter of U.S. carriers as a moderating variable. It was coded as " 0 " for non-U.S. Air Carriers and " 1 " for U.S. Air Carriers. We were able to obtain information on the domicile of the operating air carrier for each accident from the NTSB database.

\section{Environmentally Sustainable Airline}

To measure sustainable airlines, we used the matter of possession of highly fuelefficient aircraft by each airline as a moderating variable. It was coded as " 0 " for not possessing highly fuel-efficient aircraft and " 1 " for possessing highly fuel-efficient aircraft. We were able to obtain information on what kind of aircraft each airline possessed yearly from an official airline guide (OAG) for U.S. airlines and from the website www.planespotters.net/ (accessed on 5 October 2021) [59] for the rest of the world. The list of highly fuel-efficient aircraft such as B787-9, B747-8, A350, and A380 was collected from each manufacturer's official website $[48,49]$.

\subsubsection{Control Variables}

Control variables were chosen based on prior studies on learning from failure; these studies revealed several factors that play a role in lowering the accident rate. The first control variable we set was the size of the airline as it is known that larger airlines have lower accident rates, as larger airlines tend to have abundant resources to invest in safety equipment $[19,26]$. Following Haunschild and Sullivan [19], we measured this variable using revenue per passenger miles (in thousands) flown [26]. This variable was gathered annually based on each airline. Due to high skewness, the logarithm of the variable was used. The data were found through the U.S. Department of Transportation. Airline age was used as the second control variable; we calculated this variable using the number of years since the airline's establishment $[26,60,61]$. Due to high skewness, we used the logarithm of this variable. Third, we controlled for generalists/specialists as prior research by Haunschild and Sullivan [19] revealed that generalists are better at vicarious learning and lowering accident rates, as they have easier access to external information and are therefore more responsive to external threats [19]. This generalist variable was calculated using a widely accepted measure of fleet diversity. Fleet diversity can be calculated using the following formula: fleet diversity $=\sum_{1}^{n}-[\mathrm{Pi}(\ln \mathrm{Pi})]$, intended for $\mathrm{i}=1 \ldots n$, where $\mathrm{P}$ stands for the percentage of planes in each category $i$, and $i$ corresponds to the categories of planes (e.g., Airbus A330) [19,62-64]. To compute fleet diversity, fleet size data are needed [19]. If the fleet diversity score is high, the airline tends to have diverse fleets and is, therefore, more likely to be a generalist. We collected data on the fleet size from an official airline guide (OAG) for U.S. airlines and from the website www.planespotters.net/ (accessed on 5 October 2021) [59] for the rest of the world. To take care of missing values on departures, we applied an imputation method. 


\subsection{Data Analyses}

As common data were composed of a panel of observations in terms of organizationto-year, we organized our accident data in the form of panel data set in airline-to-year format [19]. Generally, three-panel estimation models, pooled ordinary least squares (OLS), fixed effects, and random effects were present and were tested. To choose between the panel estimate model of the pooled OLS or the random-effects regression model, the Breusch and Pagan Lagrangian multiplier (LM) test was performed and found that the random effects regression model was a fitting model [65]. Additionally, to distinguish whether fixed- or random-effects regression models were suitable, the Hausman test was performed and found that a random-effects regression model was more fitting [66]. Therefore, we used a random-effects regression model for our analyses. Based on our database collected from NTSB, 231 accidents existed for worldwide (domestic and international) commercial airlines between 2008 and 2018. From the NTSB database, we were able to gain data on the previous five years due to the need to accumulate five prior years of data for most of the variables. Due to the availability of data, full sample data of 231 accidents were analyzed. We were able to obtain the accident rate on a yearly basis for our dependent variable.

\section{Results}

The descriptive statistics and correlations are presented in Table 1. Measures of variable means, standard deviations, minimums, maximums, and correlations were calculated. None of the variables showed high correlations (e.g., $r>0.85$ ) [67].

Table 1. Descriptive statistics and correlations.

\begin{tabular}{|c|c|c|c|c|c|c|c|c|c|c|c|}
\hline & Mean & Std. Dev. & Min & Max & 1 & 2 & 3 & 4 & 5 & 6 & 7 \\
\hline 1. Event rate & 6.659549 & 68.08126 & 0 & 769.23 & 1.00 & & & & & & \\
\hline 2. Airline size & 1.493291 & 2.393478 & 0 & 8.85 & -0.06 & 1.00 & & & & & \\
\hline 3. Airline age & 54.5625 & 27.28812 & 10 & 111.00 & -0.10 & 0.03 & 1.00 & & & & \\
\hline 4. Level of specialism & 1.023801 & 0.706417 & 0 & 2.16 & -0.08 & 0.03 & 0.62 & 1.00 & & & \\
\hline 5. Alliance membership & 19.26406 & 21.93387 & 0 & 97.60 & -0.08 & -0.16 & -0.13 & -0.07 & 1.00 & & \\
\hline 6. U.S. air carrier & 0.882813 & 0.322907 & 0 & 1.00 & 0.01 & -0.02 & -0.09 & 0.01 & 0.04 & 1.00 & \\
\hline 7. Sustainable airline & 0.84375 & 0.364519 & 0 & 1.00 & -0.20 & 0.08 & 0.11 & 0.13 & 0.05 & 0.18 & 1.00 \\
\hline
\end{tabular}

The statistical results of random-effects regression are presented in Table 2. In Table 2, Model 1 shows the results of the control variables. Our first control variable, airline size, was negative and showed significance, meaning that larger airlines tend to have reductions in subsequent accident rates and that learning occurred. Our second control variable, airline age, was also negative and showed significance, meaning that older airlines tend to have reductions in subsequent accident rates and that learning occurred. Our third control variable, level of specialism, showed a negative and significant effect, indicating that more specialized airlines tend to have reductions in subsequent accident rates and that learning occurred.

In Model 2, our main variable, alliance membership, was additionally attached to a list of control variables. It showed that the effect of alliance membership had a negative and significant effect, supporting Hypothesis 1: an airline is more likely to learn from alliance members' failures. As a process to examine the moderating effect, Model 3 added the moderating variable of U.S. air carriers to Model 2. In Model 4, the interaction terms were added to Model 3 to test our moderating effect. The result of interaction terms was negative and significant, supporting Hypothesis 2: U.S. air carriers are more likely to learn from alliance memberships. As a process to examine the moderating effect, Model 5 added the moderating variable of an environmentally sustainable airline to Model 2. Model 6 
presented interaction terms added to Model 5 to test our moderating effect. The result of interaction terms was negative and significant, supporting Hypothesis 3.

Table 2. Random-effects GLS models of U.S. airlines' accident rates.

\begin{tabular}{|c|c|c|c|c|c|c|}
\hline & Model 1 & Model 2 & Model 3 & Model 4 & Model 5 & Model 6 \\
\hline & b/se & b/se & b/se & b/se & $\mathrm{b} / \mathrm{se}$ & $\mathrm{b} / \mathrm{se}$ \\
\hline \multirow{2}{*}{ Airline size } & $-2.865 * * *$ & $-3.285^{* * *}$ & $-3.237^{* * *}$ & $-3.270 * * *$ & $-2.869 * * *$ & $-2.724^{* * *}$ \\
\hline & $(0.42)$ & $(0.47)$ & $(0.46)$ & $(0.47)$ & $(0.33)$ & $(0.33)$ \\
\hline \multirow{2}{*}{ Airline age } & $-1.500 * * *$ & $-1.138^{* * *}$ & $-1.156^{* * *}$ & $-1.147^{* * *}$ & $-0.037^{* * *}$ & $-0.688^{* * *}$ \\
\hline & $(0.07)$ & $(0.05)$ & $(0.05)$ & $(0.05)$ & 0.00 & $(0.04)$ \\
\hline \multirow{2}{*}{ Level of specialism } & $-0.233^{* * *}$ & $-2.175^{* * *}$ & $-2.214^{* * *}$ & $-2.143^{* * *}$ & $-0.740 * * *$ & $-0.460^{* * *}$ \\
\hline & $(0.05)$ & $(0.10)$ & $(0.10)$ & $(0.11)$ & $(0.11)$ & $(0.09)$ \\
\hline \multirow{2}{*}{ Alliance membership } & & $-0.118^{* * *}$ & $-0.120 * * *$ & $-0.060^{* * *}$ & $-0.144^{* * *}$ & $-0.104^{* * *}$ \\
\hline & & $(0.01)$ & $(0.01)$ & $(0.01)$ & $(0.01)$ & $(0.01)$ \\
\hline \multirow{2}{*}{ U.S. air carrier } & & & $-0.280 *$ & 0.027 & & \\
\hline & & & $(0.13)$ & $(0.15)$ & & \\
\hline \multirow{2}{*}{ Alliance membership $\times$ U.S. air carrier } & & & & $-0.088^{* * *}$ & & \\
\hline & & & & -0.02 & & \\
\hline \multirow{2}{*}{ Sustainable Airline } & & & & & $-3.359 * * *$ & $-3.392^{* * *}$ \\
\hline & & & & & $(0.13)$ & $(0.13)$ \\
\hline \multirow{2}{*}{ Alliance membership $\times$ Sustainable Airline } & & & & & & $-0.098^{* *}$ \\
\hline & & & & & & $(0.03)$ \\
\hline \multirow{2}{*}{ Constant } & $7.734^{* * *}$ & $6.907^{* * *}$ & $7.217^{* * *}$ & $6.916^{* * *}$ & $5.920 * * *$ & $7.026^{* * *}$ \\
\hline & $(0.24)$ & $(0.17)$ & $(0.22)$ & $(0.23)$ & $(0.07)$ & $(0.15)$ \\
\hline
\end{tabular}

${ }^{*} p<0.05,{ }^{* *} p<0.01,{ }^{* * *} p<0.001$.

\section{Conclusions}

Through our research, we discovered new factors that influence learning from failure. By discovering factors that influence lowering subsequent airline accidents, environmental sustainability can be reached [16,17]. Airline accidents could bring dreadful consequences from an environmental perspective, such as oil leaks from aircraft or uranium pollution created by the 1992 Boeing 747-258F plane crash in Amsterdam [15,18]. Thus, exploring factors to reduce accidents may induce environmental sustainability. Through this research, we examined whether alliance membership influences the lowering of the rate of subsequent airline accidents. In addition, we explored whether moderating factors, liabilities and status as an environmentally sustainable airline, strengthen the effect of alliance membership lowering subsequent accident rates.

Our research additionally offers prior research on learning from one's own error experience [19-21] and vicarious learning [22,23] by suggesting a new type of vicarious learning: in-group vicarious learning. We define alliance learning as in-group vicarious learning; through this type of learning, we expect to lower the subsequent accident rate. According to Darr et al. [25], group members, such as chain members, tend to vicariously learn; however, their interest did not lie in learning from failure. In that study, the industry chosen was the hotel industry rather than the airline industry, so the generalization of their findings is questionable in our airline setting. The results of our analysis showed that an airline is more likely to learn from alliance members' failures. We examined the moderating effect of a country with more liability; in our case, U.S. air carriers were studied, and the results revealed that U.S. air carriers are more likely to learn from alliance memberships. Alliance members share information about their accidents through regularly organized 
alliance team meetings, which leads to a reduction in the subsequent accident rate by allowing alliance members to pay attention to alliance members' accidents. In addition, we examined the moderating effect of an environmentally sustainable airline, and the results revealed that an environmentally sustainable airline is more likely to learn from alliance memberships.

Most of the previous studies on aviation have concentrated on the economic benefits of alliances [8-12]. Our research attempted to expand the benefits of alliance membership to reduce airlines' subsequent accident rates by learning from alliance members' accident experiences [22,23]. Our findings showed that alliances are a beneficial strategy rather than a promotional and superfluous partnership among airlines. Through an airline accident database, two major lines of the literature were tested: alliance and vicarious learning.

Safety is always the top priority of CEOs and managers. They indefinitely endeavor to reduce the accident rate. Many studies have revealed factors that affect accident rates in various fields $[19-23,26,29,43,68-71]$. Narrowing the scope to airline accidents, previous studies have explored factors that reduce accident rates, such as human factors (e.g., pilot [69]) [70], organizational factors [71], complexity [19], and internal attribution of errors [26], as causes of airline accidents are complex issues. Our research contributed by adding a factor in the strategy of organizations, alliances, to reduce airline accident rates. For CEOs and managers, the importance of forming alliances has been highlighted; therefore, this study encourages airlines to join an alliance to reduce accident rates. Specifically, our research findings strongly encourage non-alliance members to join alliance membership. Additionally, our findings on a moderating variable suggest that CEOs and managers should manage airlines in an environmentally sustainable way as this reduces accidents by learning from alliance members. In addition, airlines in alliance memberships are encouraged to actively share the accident information of alliance members through regular alliance meetings to reduce accident rates. Our findings revealed that due to the heavy liability of U.S. air carriers, they are more likely to learn from alliance members. For passengers, our findings suggest selecting airlines with alliance memberships, and among those who joined alliance memberships, U.S. air carriers may be better to travel with. In addition, our findings suggest that an environmentally sustainable airline is more likely to learn from alliance memberships. Our findings recommend choosing airlines under alliance memberships, and among those who have joined alliance memberships, and an environmentally sustainable airline may be better to travel with.

The limitations of these research findings persist in their application to other industry settings; however, the findings may be applied to other industries with alliance membership and accidents, such as the railroad industry, the banking industry, the automobile industry, and hospitals. We would like to motivate scholars in different fields to research from this perspective. As there is still much to be discovered regarding learning from failure, more research regarding theoretical and empirical improvement should be developed in the future.

Author Contributions: Conceptualization, E.K. and M.R.; methodology, E.K.; software, E.K.; validation, E.K. and M.R.; formal analysis, E.K.; investigation, E.K.; resources, E.K.; data curation, E.K.; writing-original draft preparation, E.K.; writing—review and editing, E.K.; visualization, E.K.; supervision, E.K. and M.R.; project administration, E.K.; funding acquisition, E.K. All authors have read and agreed to the published version of the manuscript.

Funding: This research received no external funding.

Institutional Review Board Statement: Not applicable.

Informed Consent Statement: Not applicable.

Data Availability Statement: Not applicable.

Conflicts of Interest: The authors declare no conflict of interest. 


\section{Appendix A}

Table A1. Major airline alliances and their member carriers in 2019 [3,6,72].

\begin{tabular}{|c|c|c|}
\hline Star Alliance & One World Alliance & Sky Team Alliance \\
\hline Aegean Airlines & America Airlines & Aeroflot \\
\hline Air Canada & British Airways & Aerolíneas Argentinas \\
\hline Air China & Cathay Pacific & Aeroméxico \\
\hline Air India & Finnair & Air Europa \\
\hline Air New Zealand & Iberia Airlines & Air France \\
\hline All Nippon Airways & Japan Airlines & Alitalia \\
\hline Asiana Airlines & LATAM & China Airlines \\
\hline Austrian Airlines & Malaysia Airlines & China Eastern Airlines \\
\hline Avianca & Qantas & Czech Airlines \\
\hline Brussels Airlines & Qatar Airways & Delta Air Lines \\
\hline Copa Airlines & Royal Jordanian & Garuda Indonesia \\
\hline Croatia Airlines & SriLankan Airlines & Kenya Airways \\
\hline EgyptAir & S7 Airlines & KLM Royal Dutch Airlines \\
\hline Ethiopian Airlines & & Korean Air \\
\hline EVA Air & & Middle East Airlines \\
\hline LOT Polish Airlines & & Saudia \\
\hline Lufthansa & & TAROM \\
\hline Scandinavian Airlines & & Vietnam Airlines \\
\hline Shenzhen Airlines & & XiamenAir \\
\hline \multicolumn{3}{|l|}{ Singapore Airlines } \\
\hline \multicolumn{3}{|l|}{ South African Airways } \\
\hline \multicolumn{3}{|l|}{ Swiss International Air Lines } \\
\hline \multicolumn{3}{|l|}{ TAP Air Portugal } \\
\hline \multicolumn{3}{|l|}{ Thai Airways International } \\
\hline \multicolumn{3}{|l|}{ Turkish Airlines } \\
\hline United Airlines & & \\
\hline
\end{tabular}

\section{References}

1. StarAlliance. The History of Star Alliance. Available online: https:/ /www.staralliance.com/en/history (accessed on 1 June 2020).

2. CAPA HNA Group: Four Airlines form U-FLY Alliance, World's First LCC Grouping, Showing HNA Consolidation. Available online: https:/ / centreforaviation.com/analysis/reports/hna-group-four-airlines-form-u-fly-alliance-worlds-first-lcc-groupingshowing-hna-consolidation-262418 (accessed on 1 June 2020).

3. Oneworld. Two Decades. 13 Airlines. One Bright Alliance. Available online: https://www.oneworld-20years.com/ (accessed on 1 June 2020).

4. Ch-Aviation. Vanilla Alliance Agreements Signed in Antananarivo. Available online: https://www.ch-aviation.com/portal/ news / 40422-vanilla-alliance-agreements-signed-in-antananarivo (accessed on 1 June 2020).

5. ValueAlliance. Value Alliance Partners. Available online: https://www.valuealliance.com/\#/about (accessed on 1 June 2020).

6. Skyteam. SkyTeam member airlines. Available online: https:/ / www.skyteam.com/en/about (accessed on 1 June 2020).

7. Morrish, S.C.; Hamilton, R.T. Airline alliances? Who benefits? J. Air Transp. Manag. 2002, 8, 401-407. [CrossRef]

8. Button, K.; Haynes, K.; Stough, R. Flying into the Future: Air Transport Policy in the European Union; Edward Elgar Publishing: Cheltenham, UK, 1998.

9. Hamill, T. World Airline Directory. Flight Int. 1993, 143, 39-133.

10. Brueckner, J.; Whalen, T. The price effects of international airline alliances. J. Law Econ. 2000, 43, 503-545. [CrossRef]

11. Oum, T.H.; Park, J.H.; Zhang, A. Globalisation and Strategic Alliances: The Case of the Airline Industry; Elsevier Science: London, UK, 2000.

12. Gellman Research Associates, GRA. A Study of International Airline Code Sharing; Gellman Research Associates, GRA: Washington, DC, USA, 1994.

13. Hanlon, J.P. Global Airlines: Competition in a Transnational Industry, 2nd ed.; Butterworth-Heinemann: London, UK, 1999.

14. Sissen, J. Charting a course. Airfinance J. (Suppl. Int. Cap. Mark.) 1999, 2-5.

15. Ryley, T.; Burchell, J.; Davison, L. Valuing air transportation and sustainability from a public perspective: Evidence from the United Kingdom and the United States. Res. Transp. Bus. Manag. 2013, 7, 114-119. [CrossRef]

16. Department for Environment, Food and Rural Affairs. Securing the Future: UK Government Sustainable Development Strategy; Department of the Environment, Food and Rural Affairs: London, UK, 2005. 
17. Department for Environment, Food and Rural Affairs. Measuring Progress: Sustainable Development Indicators 2010; Department for Environment, Food and Rural Affairs: London, UK, 2010.

18. De Haag, P.U.; Smetsers, R.; Witlox, H.; Krus, H.; Eisenga, A. Evaluating the risk from depleted uranium after the Boeing 747-258F crash in Amsterdam, 1992. J. Hazard. Mater. 2000, 76, 39-58. [CrossRef]

19. Haunschild, P.R.; Sullivan, B.N. Learning from complexity: Effects of prior accidents and incidents on airlines' learning. Adm. Sci. Q. 2002, 47, 609-643. [CrossRef]

20. Denrell, J. Vicarious learning, undersampling of failure, and the myths of management. Organ. Sci. 2003, 14, 227-243. [CrossRef]

21. Haunschild, P.R.; Rhee, M. The role of volition in organizational learning: The case of automotive product recalls. Manag. Sci. 2004, 50, 1545-1560. [CrossRef]

22. Baum, J.; Ingram, P. Survival-Enhancing Learning in the Manhattan Hotel Industry. Manag. Sci. 1998, 44, 1898-1980. [CrossRef]

23. Miner, A.S.; Mezias, S.J. Ugly duckling no more: Pasts and futures of organizational learning research. Organ. Sci. 1996, 7, 88-99. [CrossRef]

24. Maloo, M.C.; Darrow, W.P. Potential liabilities of US airlines: Management concerns for cost and consequences of code sharing alliances in civil aviation. Am. Bus. Rev. 2001, 19, 121-129.

25. Darr, E.D.; Argote, L.; Epple, D. The acquisition, transfer, and depreciation of knowledge in service organizations: Productivity in franchises. Manag. Sci. 1995, 41, 1750-1762. [CrossRef]

26. Kim, E.; Rhee, M. How airlines learn from airline accidents: An empirical study of how attributed errors and performance feedback affect learning from failure. J. Air Transp. Manag. 2017, 58, 135-143. [CrossRef]

27. Chuang, Y.-T.; Baum, J.A. It's all in the name: Failure-induced learning by multiunit chains. Adm. Sci. Q. 2003, 48, 33-59. [CrossRef]

28. Kim, J.-Y. Crash Test without Dummies: A Longitudinal Study of Interorganizational Learning from Failure Experience in the U.S. Commercial Banking Industry, 1984-1998; Academy of Management Proceedings, 2000; Academy of Management: Briarcliff Manor, NY, USA, 2000; pp. G1-G6.

29. Kim, J.-Y.; Miner, A.S. Vicarious learning from the failures and near-failures of others: Evidence from the US commercial banking industry. Acad. Manag. J. 2006, 50, 687-714. [CrossRef]

30. Weick, K.; Sutcliffe, K.M.; Obstfeld, D. Organizing for High Reliability: Processes of Collective Mindfulness. In Research in Organizational Behavior; Elsevier: New York, NY, USA, 1999; Volume 21, pp. 81-123.

31. Levitt, B.; March, J.G. Organizational learning. Ann. Rev. Sociol. 1988, 14, 319-338. [CrossRef]

32. Baum, J.A.; Dahlin, K.B. Aspiration performance and railroads patterns of learning from train wrecks and crashes. Organ. Sci. 2007, 18, 368-385. [CrossRef]

33. Miner, A.S.; Haunschild, P.R. Population-level learning. Res. Organ. Behav. 1995, 17, 115-166.

34. Miner, A.S.; Kim, J.-K.; Holzinger, I.W.; Haunschild, P. Fruits of failure: Organizational failure and population level learning. Adv. Strateg. Manag. 1999, 16, 187-220. [CrossRef]

35. Argote, L. Organizational Learning: Creating, Retaining and Transferring Knowledge; Kluwer Academic: Norwell, MA, USA, 1999.

36. Ingram, P.; Baum, J.A. Interorganizational learning and the dynamics of chain relationships. Adv. Strateg. Manag. 2001, 18, 109-139.

37. Mitchell, W.; Baum, J.A.; Banaszak-Holl, J.; Berta, W.B.; Bowman, D. Opportunity and constraint: Chain-to-component transfer learning in multiunit chains of U.S. nursing homes, 1991-1997. In Strategic Management of Intellectual Capital and Organizational Capital and Organizational Knowldege; Oxford University Press: New York, NY, USA, 2002; pp. 555-574.

38. Baum, J.A.C.; Li, S.X.; Usher, J.M. Making the next move: How experiential and vicarious learning shape the locations of chains' acquisitions. Adm. Sci. Q. 2000, 45, 766-801. [CrossRef]

39. Baum, H.; Auerbach, S. Strategic Management in the Aviation Industry; Taylor \& Francis: London, UK, 2017.

40. Staralliance.com. Star Alliance Celebratess 20 Years of Connecting People and Cultures. Available online: https://www. staralliance.com/fr/news-article?newsArticleId=PR_20TH\&groupId=20184 (accessed on 5 October 2021).

41. Cho, C. Asiana Airlines Holds Star Alliance CEO Meeting in Seoul. The Korea Herald. 2 June 2019. Available online: http: / / www.koreaherald.com/view.php?ud=20190602000173 (accessed on 5 October 2021).

42. Kong, K. Airline Alliance Helped in Crash Aftermath. The Wall Street Journal. 9 July 2013. Available online: https:/ /www.wsj. com/articles/BL-KRTB-3874 (accessed on 5 October 2021).

43. Rhee, M.; Haunschild, P.R. The liability of good reputation: A study of product recalls in the US automobile industry. Organ. Sci. 2006, 17, 101-117. [CrossRef]

44. McKenry, C.E., Jr. Judicial jurisdiction under the Warsaw Convention. J. Air Law Commer. 1963, $29,205-229$.

45. Speiserkrause. Our Work and Past Cases. Available online: https://speiserkrause.com/lawyer/Our-Work-and-Past-Cases_cp1 4522.htm (accessed on 5 October 2021).

46. Kreindler. Kreindler Wins on Behalf of Victims in Continental Connection/Colgan Flight 3407 Crash Buffalo, New York. Available online: https:/ / www.kreindler.com/Recent-Developments/Colgan-Air-Flight-3407-Pinnacle-Airlines-Bankruptcy. shtml (accessed on 5 October 2021).

47. KoreanAir. Sustainability (ESG) Report. Available online: https://www.koreanair.com/de/en/footer/about-us/sustainablemanagement/report (accessed on 5 October 2021). 
48. Boeing. Commercial Aviation and the Environment. Available online: https://www.boeing.com/resources/boeingdotcom/ principles/environment/pdf/ecoMagazine.pdf (accessed on 5 October 2021).

49. Airbus. Delivering Eco-Efficiency. Available online: https://www.airbus.com/aircraft/passenger-aircraft/environment.html (accessed on 5 October 2021).

50. Song, G. Korean Air Make Strides in Green Campaign via Upgrade in Aircrafts and Fuel. Available online: https://m.pulsenews co.kr $/$ view.php?sc=30800028\&year $=2021 \&$ no $=870970$ (accessed on 5 October 2021).

51. Kim, J. Korean Air to Buy 11 Fuel-Efficient Boeing Aircraft. Available online: https://m.koreatimes.co.kr/pages/article.asp? newsIdx=137807 (accessed on 5 October 2021).

52. Kozuba, J.; Ojciec, M. Overview of historical and future trends of commercial aircraft fuel efficiency. Acta Avion. J. 2019, 21, 12-17. [CrossRef]

53. Dzhengiz, T.; Niesten, E. Competences for Environmental Sustainability: A Systematic Review on the Impact of Absorptive Capacity and Capabilities. J. Bus. Ethics 2020, 162, 881-906. [CrossRef]

54. Sun, P.Y.; Anderson, M.H. An examination of the relationship between absorptive capacity and organizational learning, and a proposed integration. Int. J. Manag. Rev. 2010, 12, 130-150. [CrossRef]

55. Todorova, G.; Durisin, B. Absorptive capacity: Valuing a reconceptualization. Acad. Manag. Rev. 2007, 32, 774-786. [CrossRef]

56. Fromm, G. Aviation safety. Law Contemp. Probl. 1968, 33, 590-618. [CrossRef]

57. NTSB. Code of Federal Regulations. In Title 49; Part 830; NTSB: Washington, DC, USA, 2001; Volume 5, Chapter 8.

58. Rose, N.L. Profitability and product quality: Economic determinants of airline safety performance. J. Political Econ. 1990, 98 Pt 1 , 944-964. [CrossRef]

59. Planespotters.net. Available online: https:/ /www.planespotters.net/ (accessed on 5 October 2021).

60. Hannan, M.T.; Freeman, J. Structural inertia and organizational change. Am. Sociol. Rev. 1984, 49, 149-164. [CrossRef]

61. Ruef, M. Assessing organizational fitness on a dynamic landscape: An empirical test of the relative inertia thesis. Strateg. Manag. J. 1997, 18, 837-853. [CrossRef]

62. Carroll, G.R. Concentration and specialization: Dynamics of niche width in populations of organizations. Am. J. Sociol. 1985, 90, 1262-1283. [CrossRef]

63. Seidel, M.-D.L. Competitive Realignment in the Airline Industry: A Dynamic Analysis of Generalist and Specialist Organizations under Different Route Network Structures; University of California: Berkeley, CA, USA, 1997.

64. Dobrev, S.D.; Kim, T.-Y.; Hannan, M.T. Dynamics of niche width and resource partitioning. Am. J. Sociol. 2001, 106, 1299-1337. [CrossRef]

65. Breusch, T.S.; Pagan, A.R. The Lagrange multiplier test and its applications to model specification in econometrics. Rev. Econ. Stud. 1980, 47, 239-253. [CrossRef]

66. Hausman, D.M. Economic methodology in a nutshell. J. Econ. Perspect. 1989, 3, 115-127. [CrossRef]

67. Mason, C.H.; Perreault, W.D. Collinearity, power and interpretation of multiple regression analysis. J. Mark. Res. 1991, 28, 268-280. [CrossRef]

68. Bruning, E.R.; Kuzma, A.T. Airline accidents and stock return performance. Logist. Transp. Rev. 1989, 25, $157-168$.

69. Boyd, D.D.; Scharf, M.; Cross, D. A comparison of general aviation accidents involving airline pilots and instrument-rated private pilots. J. Saf. Res. 2021, 76, 127-134. [CrossRef]

70. Kelly, D.; Efthymiou, M. An analysis of human factors in fifty controlled flight into terrain aviation accidents from 2007 to 2017 . $J$ Saf. Res. 2019, 69, 155-165. [CrossRef]

71. Xue, Y.; Fu, G. A modified accident analysis and investigation model for the general aviation industry: Emphasizing on human and organizational factors. J. Saf. Res. 2018, 67, 1-15. [CrossRef] [PubMed]

72. StarAlliance. Star Alliance Member Airlines. Available online: https://www.staralliance.com/en/home (accessed on 1 June 2020). 